\title{
The Correlation Between Physical Activity, Body Mass Index (BMI), and Abdominal Circumference with Type 2 Diabetes Mellitus (DM) Cases at Public Health Center Dinoyo Malang
}

\author{
$1^{\text {st }}$ Yogi Imansary \\ Department of Public Health \\ Universitas Negeri Malang) \\ Malang, Indonesia \\ imansary.yogi.1506126@students.um.ac.id
}

\author{
$2^{\text {nd }}$ Moch. Yunus \\ Department of Public Health \\ Universitas Negeri Malang \\ Malang, Indonesia \\ moch.yunus.fik@gmail.com
}

\author{
$3^{\text {rd }}$ Rara Warih Gayatri* \\ Department of Public Health \\ Universitas Negeri Malang \\ Malang, Indonesia \\ rara.warih.fik@um.ac.id
}

\begin{abstract}
Diabetes Mellitus (DM) is the top 10 disease with highest patients in Indonesia and the highest prevalence is in East Java Province. Dinoyo Public Health Center was one of the most recipients of patients in 2018 with total of 10,355 Type 2 Diabetes Mellitus patients aged 40-69 years old. The modifiable risk factors for Type 2 Diabetes Mellitus include physical activity, body mass index (BMI), and abdominal circumference. This study aims to determine the correlation between physical activity, BMI, and abdominal circumference with Type 2 Diabetes Mellitus at Dinoyo Public Health Center Malang. This study is a quantitative study with cross sectional approach as correlational study method. The sample of this study were patients aged more than 40 years old at Dinoyo Public Health Center. Based on the analysis of bivariate test using the chi square test, there was the correlation between physical activity, body mass index (BMI), and abdominal circumference with Type 2 Diabetes Mellitus (DM) at Public Health Center Dinoyo Malang. According to multiariate test using the BMI regression test, it was found that BMI had eight times greater effect on triggering Type 2 Diabetes Mellitus at Dinoyo Public Health Center Malang.
\end{abstract}

Keywords - physical activity, BMI, abdominal circumference, Diabetes Mellitus.

\section{INTRODUCTION}

Diabetes Mellitus (DM) is a chronic metabolic disorder due to the pancreas cannot be able to produce sufficient insulin or the body unable to use insulin effectively ${ }^{1}$. This disease still threatens public health around the world. Based on data in 2012 that around 1.5 million people worldwide have lost their lives due to diabetes ${ }^{2}$. Indonesia is the fourth country with the highest prevalence of DM in the world ${ }^{3}$. Diabetes is the top 10 of most common diseases in Indonesia and the highest prevalence is in East Java Province ${ }^{4}$.

DM risk factors are divided into two factors, namely modified and cannot be modified ${ }^{5}$. Modifiable risk factors for Type 2 Diabetes Mellitus may worsen include obesity, physical inactivity, hypertension, dyslipidemia, and an unhealthy diet or high sugar and low fiber diet ${ }^{6}$. Obesity is closely related to BMI and affects abdominal circumference ${ }^{7}$. It is due to the lack of physical activity and unbalanced diet ${ }^{7}$.

Obesity is a pathological condition with metabolic changes due to insulin resistance ${ }^{5}$. Controlling obesity can be done by measuring abdominal circumference ${ }^{8}$. Abdominal circumference or central obesity is dangerous accumulation of fat in the abdomen due to the adipocyte in this area is efficient and more resistant to insulin efffect than other parts of body ${ }^{9}$. The way of controlling blood sugar for diabetes patients is physical activity ${ }^{10}$. This physical activity plays role in controlling blood sugar by converting glucose into energy ${ }^{11}$.

The cases of Type 2 Diabetes Mellitus in Malang, 2018 from January to September, the total number of Type 2 Diabetes Mellitus patients was 10,355 people of 40-69 years 12. The public health center that handle many cases of Type 2 Diabetes Mellitus is Dinoyo Public Health Center, Kedungkandang Public Health Center, and Janti Public Health Center with 1,800 patients in average ${ }^{12}$. The high prevalence of DM proves that DM is a serious problem in the public health sector ${ }^{13}$. The risk factor is one of the correct preventive measures to reduce the prevalence of Type 2 Diabetes Mellitus patients ${ }^{9}$. Based on the background of problem above, the writer is interested to discuss about the correlation between physical activity, body mass index (BMI), and abdominal circumference with Type 2 Diabetes Mellitus (DM) at Public Health Center Dinoyo Malang.

\section{METHOD}

The study design is a quantitative study with a cross sectional approach as correlational study method. The correlational study method aims to determine whether there is a tendency for the correlation between one variable to another ${ }^{14}$. Cross sectional is a study design that obtain study variables at the same time ${ }^{15}$.

Cross sectional is the epidemiological study design about the correlation between disease and its impact by observing the status of impact and disease at the same time ${ }^{16}$. The 
dependent variable of this study was diabetes mellitus, while the independent variables in this study were physical activity, BMI, and abdominal circumference. The sampling technique used in this study is quota sampling. Quota sampling is a sampling technique by grouping the target population into categories then giving the quota of subjects for each stratum ${ }^{16}$.

The sample required in this study is 73 samples. Consisting of people whose age over 40 years-old, the strata is divided into three categories with span of 10 years to classify age category easier. Bivariate analysis was used to test the related variables ${ }^{17}$. This study used the chi square test, because the data scale of this study was ordinal and nominal and included in the non-parametric statistical category. Multivariate analysis is the correlation between physical activity, BMI, and abdominal circumference with Diabetes Mellitus cases in which regression test used in multivariate analysis of this study.

\section{RESULT}

The following are the univariate results of this study.

TABLE I. FREQUENCY DISTRIBUTION

\begin{tabular}{|llc|}
\hline \multirow{2}{*}{ Variable } & \multicolumn{2}{c|}{ Total } \\
\cline { 2 - 3 } & $\boldsymbol{N}(\mathbf{N = 7 3 )}$ & $\%$ \\
\hline Education & & \\
Elementary School & 13 & 17.8 \\
Junior High School & 15 & 20.5 \\
Senior High School & 26 & 35.6 \\
College & 19 & 26.0 \\
\hline Age & & \\
40-49 & 20 & 27.4 \\
50-59 & 20 & 27.4 \\
>60 & 33 & 45.2 \\
\hline Sexes & & \\
Male & 30 & 41.1 \\
Female & 43 & 58.9 \\
\hline DM Type 2 & & \\
Yes & 43 & 58.9 \\
No & 30 & 41.1 \\
\hline Physical Activities & & \\
Light & 39 & 53.4 \\
Medium & 29 & 39.7 \\
Heavy & 5 & 6.8 \\
\hline IMT & & 11.0 \\
Skinny & 8 & 37.0 \\
Normal & 27 & 52.1 \\
Fat & 38 & 64.4 \\
\hline Stomach Circle & 47 & 35.6 \\
Yes & 26 & \\
No & & \\
\hline
\end{tabular}

Based on data presentation in Table I, the education characteristics are divided into four, namely primary school, secondary school, high school, and university with the largest percentage in high school with $35 \%$ and the lowest percentage with $17.8 \%$ in primary schools. Respondents' ages were divided into three stratums. 20 respondents are 40-49 years old, 20 respondents are 50-59 years old, and 33 respondents are over 60 years old. Meanwhile, based on gender, the majority of respondents were women with percentage of $58.9 \%$.

There are 43 out of 73 respondents or more than $50 \%$ suffered from Type 2 Diabetes Mellitus. The highest physical activity was respondents with low physical activity with percentage of $53.4 \%$ and the lowest of physical activity was $6.8 \%$ of respondents with intense physical activity. The majority of respondents are fat category in BMI with percentage of $52.1 \%, 37 \%$ of them are normal, and $11 \%$ of them are thin. There are 47 respondents exceeded the specified standard and 26 respondents did not exceed the specified abdominal circumference standard.

The following table describe three chi square tests, namely the correlation between physical activity and the cases of Type 2 Diabetes Mellitus, the correlation between BMI and the cases of Type 2 Diabetes Mellitus, and the correlation between abdominal circumference and the cases of Type 2 Diabetes Mellitus as follows:

TABLE II. The CoRrelation BETWEen PHysical ACTIVITy AND DM TYPE 2 OCCURANCE

\begin{tabular}{|c|c|c|c|c|c|c|c|c|}
\hline \multirow{2}{*}{$\begin{array}{l}\text { Physical } \\
\text { Activities }\end{array}$} & \multicolumn{4}{|c|}{ Occurrence of DM Type 2} & \multicolumn{2}{|c|}{ Total } & \multirow{2}{*}{$\begin{array}{l}\text { OR } \\
(\mathrm{CI} \\
95 \%)\end{array}$} & \multirow{2}{*}{$\begin{array}{l}p- \\
\text { value }\end{array}$} \\
\hline & No & $\%$ & Yes & $\%$ & $\mathbf{N}$ & $\%$ & & \\
\hline $\begin{array}{l}\text { PAL } \\
1.40-1.69\end{array}$ & 9 & 30.0 & 30 & 69.8 & 39 & 100 & \multirow{3}{*}{$\begin{array}{l}5.385 \\
(1.948- \\
14.881)\end{array}$} & \multirow{3}{*}{0.001} \\
\hline $\begin{array}{l}\text { PAL } \\
1.70-2.40\end{array}$ & 21 & 70.0 & 13 & 30.2 & 34 & 100 & & \\
\hline Total & 30 & 100 & 43 & 100 & 73 & 100 & & \\
\hline
\end{tabular}

Based on table above, the $p$-value is $0.001<0.05$, this means that there is significant correlation between physical activity and the cases of Type 2 Diabetes Mellitus at Dinoyo Public Health Center. Meanwhile, the value of OR $=5,385$ with confidence interval of $1,948<\mathrm{OR}<14,881$. Therefore, low physical activity respondents with PAL 1.401.69 have the smallest risk of 1,948 times and the highest risk is 14,881 times to have Type 2 Diabetes Mellitus. The data above also shows that 30 out of 39 respondents are suffer from Type 2 Diabetes Mellitus.

TABLE III. THE CORRELATION BETWEEN IMT AND OCCURANCE OF DM TYPE 2

\begin{tabular}{|c|c|c|c|c|c|c|c|c|c|}
\hline \multirow[t]{2}{*}{ IMT } & \multicolumn{4}{|c|}{ Occurrence of DM Type 2} & \multicolumn{2}{|c|}{ Total } & \multirow{2}{*}{\multicolumn{2}{|c|}{ OR (CI 95\%) }} & \multirow{2}{*}{$\begin{array}{l}p \text { - } \\
\text { value }\end{array}$} \\
\hline & No & $\%$ & Yes & $\%$ & $\mathbf{N}$ & $\%$ & & & \\
\hline$\leq 25,0$ & 23 & 76.7 & 12 & 27.9 & 35 & 100 & \multirow{3}{*}{$\begin{array}{l}0.118 \\
0.346)\end{array}$} & \multirow{3}{*}{$(0.040-$} & \multirow{3}{*}{0.000} \\
\hline$\geq 25,1$ & 7 & 23.3 & 31 & 72.1 & 38 & 100 & & & \\
\hline Total & 30 & 100 & 43 & 100 & 73 & 100 & & & \\
\hline
\end{tabular}

The table above shows $p$-value of $0.000<0.05$, so it can be concluded that there is significant correlation between BMI and the cases of Type 2 diabetes. The OR value is 0.118 or can be read as $1 / 0.118$ which is equivalent to 8,474 , with confidence interval $0.040<\mathrm{OR}<0.346$. This indicates that people with $\mathrm{BMI} \geq 25.1$ (overweight/obese) have eight times risk of Type 2 Diabetes Mellitus. Based on the table above, the respondents with Type 2 Diabetes Mellitus are 43 people and 38 people are overweight, it means that $72.1 \%$ 
were Type 2 diabetes patients at Dinoyo Public Health Center Malang.

TABLE IV. THE CORRELATION BETWEEN IMT AND OCCURANCE OF DM TYPE 2

\begin{tabular}{|c|c|c|c|c|c|c|c|c|}
\hline \multirow{2}{*}{$\begin{array}{l}\text { Stomach } \\
\text { Circle }\end{array}$} & \multicolumn{4}{|c|}{$\begin{array}{l}\text { Occurance of DM Type } \\
2\end{array}$} & \multicolumn{2}{|c|}{ Total } & \multirow{2}{*}{$\begin{array}{l}\text { OR } \\
95 \%)\end{array}$} & \multirow{2}{*}{$\begin{array}{l}p \text { - } \\
\text { value }\end{array}$} \\
\hline & No & $\%$ & Yes & $\%$ & $\mathbf{N}$ & $\%$ & & \\
\hline Yes & 14 & 46.7 & 33 & 76.7 & 47 & 100 & \multirow{3}{*}{$\begin{array}{l}3.771(1.377- \\
10.329)\end{array}$} & \multirow{3}{*}{0.008} \\
\hline No & 16 & 53.3 & 10 & 23.3 & 26 & 100 & & \\
\hline Total & 30 & 100 & 43 & 100 & 73 & 100 & & \\
\hline
\end{tabular}

The test results of chi square in Table IV shows that the pvalue of 0.008 while the $\mathrm{OR}$ value of 3.771 . P-value smaller than the value $\alpha=0.05$ means that there is significant correlation between abdominal circumference with cases of Type 2 Diabetes, while the OR value among the confidence interval values is $1.377<\mathrm{OR}<10.329$. Therefore, the abdominal circumference of more than 80 for women and 90 for men, the risk is lowest risk two times and the highest risk is up to ten times. The table above show that there are 47 people with excess abdominal circumference and 33 of them suffer from Type 2 Diabetes at Dinoyo Public Health Center Malang.

This following table describe the correlation between three independent variables, namely physical activity, BMI, and abdominal circumference with the cases of Type 2 Diabetes at Dinoyo Public Health Center Malang.

TABLE V. DATA DESCRIPTION OF ANTHROPOMETRY MEASUREMENT AT AGE 9 YEARS OLD

\begin{tabular}{|c|c|c|c|c|c|c|}
\hline & & \multirow[t]{2}{*}{ B } & \multirow[t]{2}{*}{ Sig. } & \multirow{2}{*}{$\begin{array}{l}\operatorname{Exp} \\
\text { (B) }\end{array}$} & \multicolumn{2}{|c|}{$95 \%$ CI for $\operatorname{Exp}(B)$} \\
\hline & & & & & Lower & Upper \\
\hline \multirow[t]{3}{*}{ Step 1} & $\begin{array}{l}\text { Physical } \\
\text { Activity }\end{array}$ & 1.694 & 0.005 & 5.441 & 1.688 & 17.542 \\
\hline & IMT & $\begin{array}{l}- \\
1.827\end{array}$ & 0.007 & 0.161 & 0.043 & 0.607 \\
\hline & $\begin{array}{l}\text { Stomach } \\
\text { Circle }\end{array}$ & 0.552 & 0.426 & 1.737 & 0.446 & 6.765 \\
\hline \multirow[t]{2}{*}{ Step 2} & $\begin{array}{l}\text { Physical } \\
\text { Activity }\end{array}$ & 1.640 & 0.005 & 5.153 & 1.633 & 16.266 \\
\hline & IMT & $-\overline{2.103}$ & 0.000 & 0.122 & 0.038 & 0.389 \\
\hline
\end{tabular}

The multivariate result in Table $\mathrm{V}$ indicates that there are two of the most determiner variables as the risk factors of Type 2 Diabetes Mellitus. The variables are physical activity and BMI. Comparing both variables, BMI shows 0.122 times higher risk or $1 / 0.122$ that is equivalent to 8,197 times higher risk to have Type 2 Diabetes Mellitus with OR between confidence interval score $0.038<$ OR $<0.389$, while BMI variable is 5.153 times of risk to Type 2 Diabetes Mellitus.

\section{DISCUSSION}

\section{The Correlation between Physical Activity and Cases of Type 2 DM}

Based on findings, there is significant correlation between physical activity and the cases of type 2 diabetes mellitus at Dinoyo Publiv Health Center. It is supported with previous study about physical activity had significant correlation with the cases of type 2 diabetes, with $p$-value of $0.001^{18}$. Physical activity plays role in reducing the development of type 2 diabetes about $30-50 \%$.

This study has 33 respondents aged over 60 as majority respondents who suffer from type 2 diabetes. These respondents face difficulties. Physical activity makes insulin work effectively and helps strengthen heart ${ }^{10}$.

Physical activity is the most important component of healthy lifestyle. Regular physical activity helps to maintain normal blood glucose level and reduces the risk of type 2 diabetes. Different types of physical activity can be helpful to react against the risk of type 2 diabetes and reduce the death risk for patients with type 2 diabetes ${ }^{19}$.

The finding shows that the most respondents with low physical activity have PAL 1.40 to $1.69,39$ people out of 73 respondents. Based on questionnaire, the most respondents did activities such as watching TV and sitting. This is supported by previous study about sitting in long period and not doing physical activity will cause accumulation of calories which can lead to insulin resistance ${ }^{20}$. The women with type 2 diabetes are people with with fewer steps per day and other physical activities $^{21}$.

\section{The correlation between BMI and the cases of Type 2 DM}

In this study, the $p$-value is 0.000 , which was smaller than $a$-value, namely 0.05 , so there was significant correlation between BMI and the cases of type 2 diabetes. Moreover, if the higher BMI, the higher blood sugar level. This study is relevant with the study of Adnan, et al. (2013) that there is a significant correlation between $\mathrm{BMI}$ and type $2 \mathrm{DM}$ at Tugurejo Hospital Semarang with p-value 0.000. High BMI has double greater risk of type 2 diabetes. compared to low BMI.

$\mathrm{BMI}$ is a simple measuring tool for monitoring the nutritional status of adults. BMI is also a simple index used to classify a person's underweight, normal, overweight, and obese $^{22}$. Obesity will make the higher risk of degenerative diseases, one of them is $\mathrm{DM}^{23}$.

This study is supported by other research which has 30,133 respondents aged over 15 years old ${ }^{24}$. The results of chi square analysis is p-value of 0.0001 which has risk to diabetes mellitus of 3.378 times compared to people who are not overweight. Moreover, obesity is one of predisposing factors that improve blood sugar as DM indicator ${ }^{24}$. 
Generally, obesity is one of causes that improve risk of type 2 diabetes ${ }^{25}$. In this study, respondents who had a BMI $\geq 25.1$ were 38 people and $72.1 \%$ had type 2 diabetes. Normal BMI had 2.07 times risk to DM compared to those who were thin ${ }^{26}$. Meanwhile, respondents with excess BMI have a 3.7 times risk to diabetes, and also one kilogram of body weight can improve the risk of diabetes by $4.5 \%{ }^{26}$. The worst the obesity, the greater the risk to have DM. The negative impact of obesity is insulin resistance, which is the inability of insulin to produce normal biological functions or the degradation of insulin sensitivity. This is indicated by improvement in the amount of fasting insulin that improve blood glucose levels. Obesity in society is related to insulin resistance and DM.

\section{The Correlation between Abdominal Circumference and the Cases of Type 2 Diabetes}

The findings shows that there is significant correlation between abdominal circumference and the cases of type 2 diabetes at Dinoyo Public Health Center. P-value of 0.008 is smaller than the value of $a=0.05$, so that $\mathrm{Ha} \mathrm{Ho}$ accepted and rejected. This study is relevant with previous studies which had p-value of 0.023 that less than 0.05 , which indicates the correlation between abdominal circumference and blood sugar levels for adult people with high risk of type 2 diabetes ${ }^{27}$. This is supported by OR of 8,419 , which means that people with excess waist circumference will have eight times risk to type 2 diabetes.

The Waist to Hip Ratio has positive correlation value with p-value of $0.005^{28}$. This study shows that central obesity or accumulation of body fat in the stomach is very dangerous because adipocytes in abdominal area are efficient and more resistant to insulin than adipocytes in other areas. Excess abdominal circumference is a risk factor that can improve insulin resistance.

Insulin resistance is initial phase of metabolic abnormality until glucose intolerance occurs. It is this pancreatic cell failure that causes inadequate insulin secretion. Therefore, there was a transition from insulin resistance to diabetes. The causes of high abdominal circumference include lifestyle, diet, and inactivity. Moreover, there are factors of age and genetic factors ${ }^{29}$. The findings are consistent to theory that abdominal fat is the most dangerous fat. There are 47 out of 73 respondents in this study had excess abdominal circumference.

Central obesity based on abdominal circumference play active role as risk factor for diabetes ${ }^{30}$. Farida states that central obesity is one of metabolic syndrome. The metabolic syndrome is collection of symptoms that improving the risk of cardiovascular disease and diabetes. The metabolic syndrome can occur to one out of five people and its prevalence higher based on age.
The Correlation between Physical Activity, BMI, and Abdominal Circumference with Type 2 DM

The multivariate test results used logistic regression test. In this study, the results obtained from the previous bivariate test that three variables in this study impact on the cases of Type 2 diabetes mellitus in Dinoyo Public Health Center Malang. These three variables are candidates for logistic regression test.

The first logistic regression test of abdominal circumference has significance value of more than 0.05 , which is equal to 0.426 . This study is supported by previous study which shows that no significant correlation between central obesity and the cases of Type 2 diabetes in Janti Public Health Center ${ }^{30}$. The results of chi square test showed that $p$-value $=0.851$ which was greater than 0.05 . It happened due to the average abdominal circumference is not more than the normal standard for both men and women, 86 $\mathrm{cm}$ for men and $80 \mathrm{~cm}$ for women ${ }^{30}$.

The next test has result on significance value of 0.005 physical activity and BMI of 0.000 . Moreover, the OR value of 5.153 for physical activity and 0.12 for BMI. Physical activity is only five times smaller than BMI with eight times risk, this is due to the most of respondents are elderly and housewives who have less mobility. Having rest is important role for health, but for patients with DM, it is an inhibitor of hypoglycemia ${ }^{31}$.

The results of the multivariate analysis of three factors, the BMI variable is 0.12 times greater or $1 / 0.122$ which is equivalent to 8.19 times greater risk of Type 2 diabetes. The findings also show the OR value between the internal values confidence $0.038<\mathrm{OR}<0.389$ with significance value of $0.00{ }^{32}$. Excess BMI is due to low physical activity and high consumption of carbohydrates, protein, and fat. It impacts to the improvement of fatty acids or Free Fatty Acid (FFA) in the cells. The higher fatty acids, the lower the translocation of glucose transporter to the plasma membrane and causes insulin resistance in adipocytes muscle tissue $^{32}$

Obesity is the risk factor for type 2 diabetes. Excessive and continuous intake of nutritional foods without balanced physical activity causes fat accumulation 33 . Moreover, some influence factors of the cases of Type 2 DM include age, genetic, and gender.

In this study, 30 respondents suffered from excessive BMI. This study is supported by a study in the United States that among 11,400 women, there are women with BMI of 22$26.9 \mathrm{~kg} / \mathrm{m}^{2}$, the risk of suffering from Type 2 diabetes is eight times greater and this risk will improve 40 times greater for woman with $\mathrm{BMI}>31 \mathrm{~kg} / \mathrm{m}^{2} 34$.

\section{CONCLUSION}

1. There is significant correlation $(p$-value $=0.001)$ between physical activity and the cases of type 2 diabetes mellitus. 
2. There is significant correlation ( $p$-value $=0.000$ ) between BMI and the cases of type 2 diabetes.

3. There is significant correlation $(p$-value $=0.008)$ between abdominal circumference and the cases of type 2 diabetes.

4. BMI has eight times greater effect on type 2 diabetes with significance of 0.000 .

\section{REFERENCES}

[1] Kementrian Kesehatan RI, Upaya Pengendalian Faktor Risiko PTM. Jakarta: Kemenkes RI, 2014.

[2] World Health Organization, "Diabetes Infographic." WHO, 2016, [Online]. Available: www.who.int/entity/diabetes/globalreport/WHD2016_Diabetes_Infographic_v2.pdf?ua=1

[3] Badan Pusat Statistik, "Kota Malang Dalam Angka 2017," Badan Pusat Statistik, 2017.

[4] Dinas Komunikasi dan Informatika, "Profil." Kominfo Jatim, 2015, [Online]. Available: www.kominfo.jatimprov.go.id.

[5] Kementrian Kesehatan RI, Buku Pintar POSBINDU PTM: Penyakit Tidak Menular dan Faktor Risiko. Jakarta: Kemenkes RI, 2014.

[6] Tjandra, Hans, Penderita Diabetes Boleh Makan Apa Saja: Pandual Lengkap tentang Diet dan Cara Mengaturnya untuk Penderita Diabetes. Jakarta: Gramedia Pustaka Utama, 2011

[7] Pusat Data dan Informasi Kementrian Kesehatan RI, Situasi dan Analisis Diabetes. Jakarta: Kemenkes RI, 2014.

[8] M. Iqbal, "Hubungan Antara Ukuran Lingkar Pinggang Dengan Kadar Gula Darah Postprandial Pada Anggota Kepolisian Resor Karanganyar," s1, Universitas Muhammadiyah Surakarta, 2014

[9] Kementrian Kesehatan RI, Petunjuk Teknis Pengukuran Faktor Risiko Diabetes Melitus. Jakarta: Badan Penelitian dan Pengembangan Kesehatan Kementerian Kesehatan RI, 2010.

[10] Irianto, Koes, Epidemiologi Penyakit Menular dan Tidak Menular. Bandung: Alfabeta, 2014

[11] Kementrian Kesehatan RI, Pengukuran Faktor Risiko PTM. Jakarta: Kemenkes RI, 2014.

[12] Dinas Kesehatan Kabupaten Malang, "Profil Kesehatan Kabupaten Malang 2016." Dinas Kesehatan Kabupaten Malang, 2016, Accessed: Jul. 21, 2019. [Online]. Available: http://dinkes.malangkab.go.id.

[13] Y. P. Pamungkas and R. W. Gayatri, "Correlation Between Social Support And Strees Level on The Elderly Patients of Diabetes Melitus Type 2," Feb. 2019, pp. 215-219, Accessed: Oct. 26, 2020. [Online]. Available: https://www.atlantis-press.com/proceedings/icssh$18 / 55914064$

[14] Budiwanto, S., Metodologi Penelitian dalam Keolahragaan. Malang: UM Press, 2017.

[15] N. D. N. Ermona and B. Wirjatmadi, "Hubungan Aktivitas Fisik dan Asupan Gizi dengan Status Gizi Lebih Pada Anak Usia Sekolah Dasar di SDN Ketabang 1 Kota Surabaya Tahun 2017," AMNT, vol. 2, no. 1, p. 97, Mar. 2018, doi: 10.20473/amnt.v2i1.2018.97-105

[16] Murti, B, Desain dan Ukuran Sampel untuk Penelitian Kuantitatif dan Kualitatif di Bidang Kesehatan. Yogyakarta: Gadjah Mada University Press, 2013.

[17] Notoatmodjo, S., Ilmu Perilaku Kesehatan. Jakarta: Rineka Cipta, 2014.

[18] A. N. Kistianita, M. Yunus, and R. W. Gayatri, "Analisis Faktor Risiko Diabetes Mellitus Tipe 2 pada Usia Produktif dengan Pendekatan Who Stepwise Step 1 (Core/Inti) Di Puskesmas Kendalkerep Kota Malang,'
Preventia : The Indonesian Journal of Public Health, vol. 3, no. 1, Art no. 1, Jun. 2018, doi: 10.17977/um044v3i1p85-108.

[19] SN Bogatyrev, "Physical Activity and Type 2 Diabetes Mellitus Risk Population Studies Review. Institute of International and Preventive Medicine," Institute of International and Preventive Medicine, vol. 19, pp. 486-493, 2016.

[20] L. Nurayati and M. Adriani, "Hubungan Aktifitas Fisik dengan Kadar Gula Darah Puasa Penderita Diabetes Melitus Tipe 2," Amerta Nutrition, vol. 1, no. 2, Art. no. 2, Oct. 2017, doi 10.20473/amnt.v1i2.2017.80-87.

[21] J. Kelly, K. Edney, C. Moran, V. Srikanth, and M. Callisaya, "Gender Differences in Physical Activity Levels of Older People With Type 2 Diabetes Mellitus," J Phys Act Health, vol. 13, no. 4, pp. 409-415, 2016, doi: 10.1123/jpah.2015-0147

[22] World Health Organization, "Diabetes Fakta dan Angka." WHO, 2016, [Online]. Available: http://www.searo.who.int/indonesia/toics/8whd2016-diabetes-facts-and-numbers-indonesia.pdf.

[23] S. T. Handayani, Hubaybah, and D. Noerjoedianto, "Hubungan Obesitas Dan Aktivitas Fisik Dengan Kejadian Diabetes Melitus Tipe II di Wilayah Kerja Puskesmas Olak Kemang Tahun 2018," JKMJ, vol. 2, no. 1, Art. no. 1, Mar. 2018, doi: 10.22437/jkmj.v2i1.6535.

[24] P. S. Nugroho and A. C. Wijayanti, "Indeks Masa Tubuh dan Kaitannya dengan Diabetes Melitus pada Umur > 15 Tahun di Indonesia, Studi Data Survei Kehidupan Keluarga Indonesia V," Jurnal Publikasi Kesehatan Masyarakat Indonesia, vol. 5, no. 1, Art. no. 1, Apr. 2018, doi: 10.20527/jpkmi.v5i1.4998.

[25] J. Wang, H. Wang, J. Liu, and J. Ma, "[The association between body mass index, waist circumference with body fat percent, and abdominal fat rate in overweight and obese pupils]," Zhonghua Yu Fang Yi Xue Za Zhi, vol. 47, no. 7, pp. 603-607, Jul. 2013.

[26] N. Luthansa and D. Pramono, "Indeks massa tubuh dan kejadian diabetes melitus pada penduduk dewasa di Indonesia: analisis data IFLS tahun 2015," Berita Kedokteran Masyarakat, vol. 33, no. 4, Art. no. 4 Apr. 2017, doi: 10.22146/bkm.17734

[27] A. H. Setiawan, "Hubungan Antara Lingkar Pinggang, Lingkar Perut dan Lingkar Lengan Atas dengan Tekanan Darah Sistolik dan Diastolik pada Mahasiswa di Daerah Istimewa Yogyakarta," Universitas Gadjah Mada, 2015

[28] H. A. Rahmy, T. Triyanti, and R. A. D. Sartika, "Hubungan IMT, RLPP dan Riwayat Diabetes pada Keluarga dengan Kadar Gula Darah Sewaktu pada PNS," Jurnal Kesehatan Masyarakat Andalas, vol. 9, no. 1, Art. no. 1, Mar. 2015, doi: 10.24893/jkma.v9i1.214.

[29] Irawan, Dedi, "Prevalensi dan Faktor Risiko Kejadian Diabetes Melitus Tipe 2 di Daerah Urban Indonesia (Analisa Data Sekunder Riskesdas 2007)." Universitas Indonesia, 2010, [Online]. Available: http://lib.ui.ac.id/file?file=digital/20267101-T\%2028492Prevalensi\%20dan\%20faktor-full\%20text.pdf

[30] B. S. Mahfudzoh, M. Yunus, and S. P. Ratih, "Hubungan Antara Faktor Risiko Diabetes Melitus yang Dapat Diubah Dengan Kejadian DM Tipe 2 di Puskesmas Janti Kota Malang,” Sport Science and Health, vol. 1, no. 1, Art. no. 1, Oct. 2019

[31] Eko, "Olmesartan Meningkatkan Risiko Kematian pasien pada Diabetes Mellitus," Cermin Dunia Kedokteran, vol. 38, 2010.

[32] E. Teixeira-Lemos, S. Nunes, F. Teixeira, and F. Reis, "Regular physical exercise training assists in preventing type 2 diabetes development: focus on its antioxidant and anti-inflammatory properties," Cardiovasc Diabetol, vol. 10, p. 12, Jan. 2011, doi: 10.1186/1475-2840-10-12 
[33] Sugiyono, Patofisioogi Diabetes Melitus dalam Buku Penatalaksanaan Diabetes Melitus Terpadu sebagai Panduan Pelaksanaan Diabetes Melitus bagi Dokter Maupun Edukator Diabetes. Jakarta: Fakultas Kedokteran Indonesia, 2011.
[34] Witjaksono, F., “Obesitas Bukan Lagi Tanda Kemakmuran,” 2004. 